\title{
Prosocial Orientation of an Organisation: The Preliminary Identification of Evaluation Criteria
}

\author{
Małgorzata Adamska-Chudzińska ${ }^{1, *}$ \\ ${ }^{1}$ Faculty of Economics and International Relations, Department of Psychology and Didactics, Cracow University of \\ Economics, Cracow, Poland \\ *Correspondence: Faculty of Economics and International Relations, Department of Psychology and Didactics, \\ Cracow University of Economics, ul. Rakowicka 27, 31-510 Cracow, Poland. E-mail: achm@uek.krakow.pl
}

Received: October 12, 2015

Accepted: November 21, 2015 Online Published: January 5, 2016

doi:10.5430/mos.v3n1p27

URL: http://dx.doi.org/10.5430/mos.v3n1p27

\begin{abstract}
Prosocial orientation of an organisation consists in such organising of an activity, in which universal social values are taken on as valuation criteria and evaluations of economic activities. In this case, a social dimension of economic activities constitutes an important aspect of implementation of a strategy and improving competitiveness of an organisation. Practical solutions including social aspects in an organisation's activity are not satisfactory enough. Organisations do not have sufficient determinants for developing prosocial orientation facilitating economic rationality. The aim of the article is to present major signs of prosocial activity of an organisation and exemplification research verifying those activities as determining and evaluating factors of a degree of prosocial orientation in an organisation's activity. On the basis of a review of the literature from the field of taking socially responsible actions by an organisation, an author's classification of prosocial actions has been formulated. Four areas of such actions have been distinguished i.e.: 1. reliable implementation of qualitative requirements, 2. improvement of activities through elimination of losses, 3. axiological orientation of managers' attitudes, 4. subjective treatment of employees. The method and results of research verifying presence of indicated activities in functioning of an exemplary organisation with market leadership in its sector have been presented. A high degree of prosocial involvement in the examined organisation and the relation between presented types of activities and general state of prosocial engagement have been stated. "A participation" of the areas selected to examination has been initially confirmed as really examining the prosocial orientation of an organisation. Thus, an initial justification for formulating overall evaluation of prosocial involvement on their basis has been obtained. A dominant role of subjective treatment of employees in development of analysed phenomenon and in taking all kinds of socially responsible actions has also been confirmed.
\end{abstract}

Keywords: Prosocial orientation; Prosocial action; Organisation; Subjectivity of employees

\section{Introduction}

The role of prosocial actions for functioning and development of contemporary organisations is more and more appreciated in the course of socio-economic transformation that takes place. An awareness of managers grows in terms of the influence of this type of actions not only on humanisation of an organisation's environment but also on stimulating an involvement of employees and improving competitiveness of an organisation. Thus, short-term actions of social nature not related to the strategy of an organisation, which purpose is only to improve an image of an organisation without actually including social values in its activity, are subject to criticism. Appropriately understood prosocial orientation means such an orientation of economic activity, in which prosocial actions constitute an essential aspect of a strategy of management and even a tool of achieving a competitive advantage. They consist in organising the working environment as a platform of action and cooperation, in which widely understood needs and expectations of internal stakeholders and external stakeholders, an influence of an activity on the environment are included and in which universal social values (like honesty, reliability, responsibility) are taken as criteria of valuation and evaluation of actions. As a result, not only mutual subjective treatment of stakeholders by stakeholders (in an organisation and on the market) but also an increase of actions oriented on carrying adjustments, 
improving processes, seizing new opportunities and at the same time obtaining economic benefits from it, take place. These include primarily decrease in costs and increase in profitability, growth in revenues and profits including increase in production, sales and number of customers (Bąk et al., 2007).

Despite noticing unique values inherent in the idea of prosociality and reviving the concept of human capital, practical solutions including social aspects in an organisation's activity are still not satisfactory enough. Developed social discourse on the importance of human's subjectivity and increase in social sensitivity are not fully transformed into practical actions. In practice, standards and principles produced so far face barriers in their respecting. Frequently, they are also applied in a random manner, and thus show low efficiency. Analysts draw attention to the lack of clear determinants in building organisation based on principles of economic rationality with incorporating rationality of shared interest of its members and external customers (Doktór, 2005). Attempts to define factors determining intensification of organisational culture with prosocial actions are diverse in order to make it an instrument of simultaneous achieving efficiency of an organisation and self-fulfilment of stakeholders of a company. As a consequence of this situation, organisations do not have harmonised indicators, that could help the evaluation of a degree of prosociality in their functioning. At the same time, societal expectations of practical implementation of actions in favour of employed and co-operating people increase. It was shown in conducted research (Wojtczuk-Turek, 2008) that among factors having influence on a level of activating employees the most important are those, which are connected with their societal expectations and needs and at the same time they determine performing work (an ability to perform interesting tasks, to improve, to carry out challenges, of self-reliance, to develop interests, justice and ethics of conduct in an organisation). Expecting of this aspects in the organisational culture points out to a need of an environment's humanisation and an importance of subjective treatment of employees expressed by recognition and fulfilling their social needs.

The aim of this article is to fill a certain gap, existing in the literature, in including prosocial actions in an economic activity. A task of determining and empirical verifying of important evidence of an organisation's prosocial activity as factors determining and evaluating a degree of prosocial orientation in an economic activity of a given organisation has been undertaken.

The following elements have been taken into account in the article: a review of literature on including and taking socially responsible actions by an organisation, a presentation of selected areas of possible prosocial actions in an organisation's functioning, a presentation of results of research verifying presence of indicated actions in functioning of exemplary enterprise with market leadership in its sector and a discussion on use of examined factors as criteria of verifying and evaluating of organisation's prosocial orientation.

\section{Review of Literature}

Many attempts have been made to order theory and approaches concerning ideas and socially responsible actions in an organisation's functioning (Garriga \& Mele, 2004). The position presented in this report refers to the "before profit obligation" model (Kang \& Wood, 1995) and its development i.e.the "social action" model (Wood, 2010). The first one assumes that every organisation is obliged to observe moral principles at every stage of its activity and not only after gaining profit. The second model develops this approach and pays attention to a necessity of continuous gaining societal acceptance by an organisation if it wants to achieve its basic economic objectives. Building public confidence is pointed out by many researchers as one of the basic assumptions of pursuing the idea of prosociality; however, they usually present diverse approaches in its gaining.

A voluntary nature of prosocial actions, orientation on managing relations with the stakeholders and networking are highlighted (Cetindamar \& Husay, 2007). Taking socially responsible actions, an organisation takes assumption of balancing interests of all stakeholders in conjunction with multilateral dialogue (Borkowska, 2005). Social behaviours of an organisation create capital and value of a brand to a large extent, which are created by all stakeholders satisfied with meeting their expectations and not only by customers (Chi-Shiun, Chih-Jen, Chin-Fang \& Da-Chang, 2010). Moreover, it has been shown that social reporting as a form of informing on prosocial actions being taken contributes to some extent to enhancing of stakeholders' trust and strengthening relations in the supply chain (Roszkowska, 2011). It is indicated that taking social responsibility improves workers' motivation, their loyalty and commitment to meet organisational objectives in relation to concrete groups of stakeholders (Morsing, 2009; Wach, 2015), and thereby it is shown that that type of actions as an aspect of management policies are rather oriented on selected groups of stakeholders such as shareholders or managers and not employees themselves (Maksimainen, Saariluoma \& Jakivuori, 2012). 
The analysis of conducted research points out that a positive impact of a relation between social aspects and an organisation's strategy on a competitive advantage is observed more and more frequently (Low \& Kalafut, 2004; Wagner, 2009). Some analysts believe that taking social responsibility affects growth of profits and reduce the reputational risk (Hediger, 2010), others directly prove the thesis that prosocial actions are positively correlated with a market value of a company (Beltratti, 2005; Godfrey, Merrill \& Hansen, 2009). 81 percent of 500 examined CEOs of the largest international companies indicated ethical, health and social aspects among ten key factors in an organisation's activity (Marcinkowska, 2010). In a very extensive review of literature, Beurden and Gössling (2008) demonstrated that in 68 percent of examined cases there is a positive relation between prosocial actions in corporations and financial performance. A basis of improving financial performance in connection with taken prosocial orientation are subjective organisation's relations with major groups of stakeholders. At the same time, it is emphasized that companies in the sectors with greater influence of stakeholders perform prosocial actions in a wider range (Jackson \& Apostolakou, 2010). Also W. Gasparski (2007) includes a prosocial perspective in an economic activity, postulating the idea of "triple E" i.e. effectiveness, efficiency and ethicality as interdependent values and creating axiological context in an economic activity. Aims of modern business are more and more frequently connected with both creating owners' profit and actions in social interest (Lewicka-Strzałecka, 2006).

As a part of prosocial activity, not only actions in favour of stakeholders, a subject matter of employment and participation of employed in an organisation's functioning are included but also aspects of quality, innovation of products and a subject matter of natural environment. A multifaceted approach to prosocial activity contributes to the fact that in an organisation's analysis an abandonment of perceiving it as a source of benefits for investors, earnings for employees and products for consumers takes place, and then there is a shift to an organisation's analysis as corresponding to social and environmental needs and values (Adamus-Matuszyńska, 2013; Hediger, 2010). Concrete social obligations are contained in basic social requirements and in qualitative programmes of an organisation (Brik, Rettab \& Mellahi, 2011; Maignan \& Ferrell, 2004; Pratley, 1995): towards broadly understood expectations of customers, towards a society in use of environmental resources area, towards the employed in terms of ensuring adequate working conditions. The objectives implemented within the framework of qualitative programmes incorporate ,in the author's opinion, apart from basic quality requirements also preventing unnecessary damage, improving operational processes and building durable partnership with stakeholders.

In T. Kamiński’s opinion (Kamiński \& Pomykało, 2004), the idea of social responsibility should be manifested in concern for public interest understood as protection of those values, which bring benefits for the whole society. In this aspect, particular emphasis is placed in order to, on the one hand prevent organisations from taking socially destructive actions even if they can generate profit and on the other hand their preventing and where necessary removing negative social phenomena if such have occurred as a consequence of an enterprise's activity. An implementation of the idea of social responsibility is considered as a new version of a social contract, which democratic societies need in connection with globalisation (Filek, 2010). While in terms of increasing social prosperity, whole range of programmes are undertaken that promote a social dimension of actions (Rybak, 2012). It is this level of social actions that makes a genuine enterprise's contribution to a social development.

Also, it is essential to indicate basic instruments, which an organisation with social responsibility principles can use. In conducted analysis, B. Rok (2004) lists the following instruments: ecolabelling (social labelling of products), corporate governance, ethics programmes for employees, a market of socially responsible investments, cause related marketing, marketing's social responsibility (for instance reliable information on products), standards and CSR indicators and social involvement programmes. In turn, Lopez, Garcia \& Rodriguez (2007) propose DJSI Index (Dow Jones Sustainability Index), which is used in research conducted on samples of companies varied in terms of the country of origin. The use of indicated tools in building social confidence is not to be questioned. However, they enable a comparative analysis and evaluation of a level of an organisation's prosocial involvement to a lesser extent, what is crucial in a progressive development of prosocial orientation. Similarly, other tools presented in the literature reveal some limits despite crucial advantages. Quite commonly used rating created by KLD agency (Kinder, Lydenberg, Domini) includes almost exclusively American companies despite its comprehensiveness (Benz, 2010).

A scale of implementation of prosocial activities and signs of social responsibility (Bartkowiak, 2006; Logman, 2002) is quite wide in an organisation's activity. On the basis of the undertaken review of the literature (Clark \& Viehs, 2014), it is concluded that in a process of seeking factors determining and evaluating prosocial orientation one needs to include:

- linking social factors with basic economic activity of an organisation (there is a functional relationship between an economic sphere and its social context); 
- an impact of prosocial actions on the environment and the whole society (it is essential to prevent waste of an organisation's and society's resources);

- linking attitudes and actions of managers with social values (social valuation and evaluation of economic actions is crucial);

- orientation of prosocial actions on a subjective approach to all stakeholders, especially employees (subjective relations constitute a basis in building social confidence).

The research presented below counter such recognition of signs of prosociality. An attempt of differentiating of major signs of prosocial involvement of an organisation has been made. They include actions having influence on a strategic activity and building of an organisational culture, and thus determining social dimension of economic functioning of an organisation. Among areas of prosocial involvement possible to indicate in an organisation, one needs to pay attention to (Adamska-Chudzińska, 2012b):

- relable implementation of requirements of quality programmes,

- improvement of an activity through elimination of losses,

- axiological orientation of managers' attitudes,

- subjective treatment of employees.

\section{Reliable Implementation of Qualitative Requirements}

These types of actions constituting a fundamental background for an organisation's economic functioning are at the same time a basic sign of prosocial involvement. Concrete obligations towards external customers and towards the employed as internal customers are included in qualitative requirements adopted by an organisation (Hamrol, 2013), which a quality of products considerably depends on. With this approach, effectiveness of an organisation reveals its relationship with prosocial organisational culture based on reckoning with other human being (a recipient and $a$ products manufacturer) in terms of taking care of his/her needs and expectations.

Obligations towards customers consist at a minimum level in preventing abuses in a core activity and guaranteeing their basic expectations are fulfilled by quality managers including complete and honest information, quality of products in accordance with programmes objectives etc. A good quality and safety of products are an essential factor of loyalty towards an organisation (Lulewicz-Sas, 2013). At a higher level, consumers more and more often have in mind not only fulfilling quality parameters indicating functionality and safety of products but also requirements going beyond a standard of their satisfaction (i.e. whether employment rights were respected in their production).

Care for needs and expectations of employees is mainly connected with ensuring prosocial working conditions facilitating manufacturing of high-quality products. In this case, raising awareness of employees is an essential element of prosocial working conditions, that there is an accordance between a company's high requirements and customers' expectations of high-quality products. It is revealed in improving work actions through pursuing of objectives oriented on needs of other people. A range of indicated actions determines a degree of prosocial involvement in reliable implementation of qualitative requirements area.

\section{Improvement of an Activity through Elimination of Losses}

Such actions are oriented on use of prosocial ways of improving of an organisation's activity. An important factor of success of implementing improvement projects through elimination of losses is raising ingenuity and creativity of people employed in concrete job positions. It requires appropriate approach to employees as co-responsible for organisation, valuing their expertise and experience and encouraging to critical and analytical thinking about activities of daily work. In conditions of appreciation for individual abilities and creating opportunities for their full utilisation, it is possible to formulate and launch useful proposals of changes. A sense of shared responsibility for a company's results and a possibility of own contribution to creation of values for other processes broadens an economic context of actions to include social aspects. An awareness of broader (social) determinants of performing work activities creates employees' sense of personal responsibility for diligence and improvement of those activities (Adamska-Chudzińska, 2012a).

Implementation of actions consisting in elimination of losses usually does not require large financial outlays, and as a result brings considerable savings and strengthens the pace of activity, reduces costs and improves products' quality. 
Among actions aimed at preventing situations contributing to losses, one needs to distinguish those, which take a form of rational changes in operational processes and lead to specific savings (for instance decrease in power consumption, improvement of production organisation, modification of work activities) and those, which are connected with avoiding waste production in the nonoperational sphere (i.e. perfect conservation of raw materials and materials). The range of corrections proposed by the employed and accepted for implementation by an organisation determines a degree of prosocial involvement in improvement of an activity area.

\section{Axiological Orientation of Managers' Attitudes}

Axiologically orientated managers' attitudes are reflected in ways and methods of organisation resources management, pursuing strategic objectives and also in relations with stakeholders. An axiological profile of attitudes determines integration of fundamental social values and ethical standards into forms of economic activities being taken. In this perspective, a prosocial involvement of an organisation shapes responsibility for social valuation and evaluation of economic actions, their course and effects towards all stakeholders (Surroca, Tribo \& Waddock, 2010). Inclusion of social attitudes in managers'actions determines specific wisdom of management (Chmielecka, 2004), which means integration in axiologically neutral economic knowledge of evaluative reflection showing its appropriate application and detrmining long-term growth in economic performance.

A tendency to respect social values and ethical standards, characteristic of axiological attitudes, reveals itself amongs others in natural taking responsibility for social effects of actions by managers and insensible allocation of tasks to workers; in reliable performing of work activities and creating right conditions for their carrying out; in honest informing about results of an organisation's action and work results of the employed; in fair treatment and evaluation of workers and in adopting ethical standards as practical principles of implementation of strategic tasks. Prosocial inclinations of managers' attitudes ensure integration of operational actions with social standards (Xuereb, 2009), an axiological framework of relations with stakeholders, improvement of co-operation and thus long-term positive effects of this co-operation. The range of economic actions including presence of social values and ethical standards determines a degree of prosocial involvement in this area.

\section{Subjective Treatment of Employees}

The last area includes actions consisting in an introduction of a standard of subjective treatment of workers to an organisational culture and its categorical compliance. Responsible and sensitive approach to workers is connected with non-violation of their dignity and recognition of their skills and experience.

Two levels of organisational behaviours expressing subjective attitude to the employed need to be distinguished in professional relationships. The elementary level of subjective treatment of workers is expressed in terms of respecting dignity of a worker in mutual relations, consistent observance of employee rights, labour standards and also support in maintaining balance between work and family responsibilities. In turn, a higher level of recognition of subjectivity of workers is determined by ensuring appropriate range of autonomy and responsibility at the workplace. A worker has a sense of his/her subjectivity, when he/she has an influence on a working situation (Penc, 2007). A sense of influence over working surrounding, which autonomy gives, determines a state of identification with an organisation's objectives and produces a driving force for creating solutions facilitating implementation of these objectives. An experience of respect, a sense of fully personal participation in working situations, their internal experiencing, a sene of authorship and an importance of their own actions leads to relatively higher work performance. Subjective approach to workers should be treated as another and at the same time a primal manifestation of prosocial actions.

\section{Method}

\subsection{Tasks and Research Assumptions}

The main objective of the research was to identify important manifestations of prosocial activity of an organisation and their preliminary verification as factors determining and evaluating a degree of prosocial orientation in an economic activity on the example of a given organisation.

Research tasks were executed around the following specific objectives:

-determination of an organisation's action areas being manifestations of prosocial involvement, 
-an analysis of manifestations of prosocial involvement in examined areas,

-an evaluation of a degree of prosocial involvement in examined areas,

-an overall evaluation of a degree, in which prosocial activity is taken in an examined organisation,

-verification of examined factors as actually characterising prosocial orientation.

A selection of areas for analysis was a consequence of carried out review of the literature and an author's classification of prosocial activity areas, on which an organisation can have an influence and which it can control. According to the previous presentation, these areas included the following: 1. reliability in an organisation's core activity (care for quality), 2. Improvement of activity through elimination of losses (rationality of management of an organisation's resources), 3. Axiological managers' attitudes (an axiological profile of managers' attitudes), 4. subjective treatment of workers. It was assumed that areas selected for examination constitute major platforms of social dimension of an economic activity of every organisation and co-determine its prosocial orientation; whereas, the issue of subjective attitude towards workers can be additionally treated as a condition for taking any kinds of prosocial actions. The analysis and evaluation of selected areas was to enable their verification as actually examining prosocial orientation of an organisation and verifying relevance of formulating an overall evaluation of this orientation on their basis.

\subsection{Test Area and Structure of Research Sample}

The research was conducted in one of the biggest pharmaceutical companies in Poland, which belongs to the American Corporation Valeant Pharmaceuticals International. It specialises in production of high-quality medicines, manufactured in accordance with the principles of Good Manufacturing Practice (GMP) and the requirements of world pharmacopoeias. It holds high, stable position on the national and foreign market, mainly on the area of Europe and the Far East. The strategy of the Company is based on the principle of sustainable development. The international code of ethics and the innovative operational excellence programme of Lean Six Sigma type is implemented in the Company.

The structure of the examined group included $60 \%$ of women and $40 \%$ of men. Nearly $90 \%$ of the respondents had work experience longer than 5 years. The selection of the respondents was random including job differentiation. The research involved: operational staff, who constituted $27 \%$ of all respondents, middle managers- $28 \%$, administrative officers $-25 \%$ and senior managers $-5 \%$ and technical staff $-15 \%$. This relatively uniform distribution enabled formulating of conclusions fully relating to the whole examined population.

\subsection{Data Collection}

The research process was pursued over the period 2007 - 2008 at the Department of Psychology and Didactics at the Cracow University of Economics. The survey in-depth technique and a method of document analysis and linear correlation were used for performing research activities. Four survey questionnaires specially formulated appropriately to every examined area of prosocial activity were applied as a research tool. It was essential to obtain information on how the respondents perceive the enterprise's actions simultaneously in all examined areas. The research activities were being performed on the premises of the enterprise during twelve meetings with groups of the employees on dates agreed with the management of the company. They were held during breaks, after work or after organisational meetings. Few or several employees representing a given workers' group took part in the research once. Participation of particular workers' groups in the research was a reflection of job differentiation in the company. Every respondent was provided to a paper version of a set of four questionnaires and appropriate conditions of completion the survey were ensured i.e. guaranteeing anonymity, the lack of intervation of superiors or other members of the organisation. A part of the questionnaires was removed from the obtained material after the initial verification, which was completed improperly. As it turned out in some cases, the respondents had difficulty in answering to synthesised questions (given at the end of every questionnaire) requiring making multiple choices. As a result, sets of questionnaires collected from 151 workers taking into account job differentiation were covered further research activities corresponding to the structure of workers' groups in the examined enterprise. As every person being tested completed four questionnaires relating to the particular analyzed areas, the material was obtained constituting the content of 604 thematic questionnaires. It was subject to full factual verification and further qualitative and quantitative analysis. In turn, in an document analysis the type of used documents was narrowed to credible written sources (Silverman 2013; Silverman 2014; Sztumski, 1984). The following sources were applied: 1. the enterprise's materials and publications, 2. published results of competitions and rankings, 3. press articles and 4. conference materials. 


\subsection{Data Analysis}

The qualitative analysis of the signs of prosocial involvement in relation to particular examined areas covered mainly: (1) the analysis of the importance and influence of the particular factors setting out quality of the products, the quality assurance system applied in the company and an awareness of the consumers' expectations concerning specified products' features. A detailed determinants of qualitative factors were exactly identified, (2) the analysis of the kinds and importance of particular improvement actions including those consisting in elimination of losses and preventing waste production and benefits resulting from them but also sources from which the company derives knowledge about the needed information, (3) the analysis of the social values favoured in the organisation and the scope, in which the ethical standards are respected. The important part of the carried out analysis was identification of characteristics of behaviours, to which the respondents relate the major social values, (4) the analysis of two types of behaviours expressing two levels of subjective approach to the employees (the basic and the higher). The most important on the basic level are humane treatment and respecting the workers' laws, and on the higher level - the range of autonomy in a position and perception of its conditionalities.

In the quantitative analysis and in evaluation of reliability of applied questionnaires due to the necessity of taking into account different types of questions reflecting various aspects of prosocial orientation and awareness of the workers in this issue, it was not possible to use classic measurements in the research (Cronbach's alpha, the measure of split-half reliability). However, specially developed procedure of standardisation of values of the responders' responses (Pociecha, Podolec, Sokołowski \& Zając, 1988; Sokołowski, 2010) and an aggregate indicator commonly used in the analysis of multi-characteristic objects was applied and a range of variation of obtained aggregate indicators was determined. In the procedure of standardisation few ways of making component variables comparable were applied, corresponding to the type of an expected answer to a concrete question and a structure of responses recognised as desirable from the point of view of the general criterion. The final aggregate indicator was calculated as a arithmetical average of subindices corresponding to the groups of questions from the four applied present questionnaires. The subindices were arithmetical averages of standardised component variables concerning the particular examined areas. All the components were treated as positive variables. In the further course of action, the scope of variation of the obtained aggregate indicators was determined. Five equal ranges of variation were set, to which specified degrees were allocated (a very low degree to a very high degree) of qualitative prosocial involvement. These actions enabled data comparison and determination of a degree of intensification of examined phenomena in four analysed areas and then in a general aspect.

Then a linear correlation coefficient was used in order to recognise connections between values of indicators of prosocial involvement in selected areas and in general aspect (Frankfort-Nachmias \& Nachmias, 2001; Kot, Jakubowski \& Sokołowski, 2010). Its statistical relevance was tested at relevance level of 0,05 . The applied methods and research tools and the taken procedure enabled the complex completion of the research, carrying out the analysis and the evaluation of the examined phenomena.

\section{Results and Discussion}

Standardised values of responses of the responders given to questions contained in the next survey questionnaires and calculated on their basis partial aggregate indicators for a given type of actions and in general aspect constituted the basis for the analysis. On the basis of obtained data(Note 1), it was claimed:

- In the area of reliable implementation of qualiy requirements of products the aggregate index of intensification of prosocial actions amounted to 0,65 (the standard deviation 0,18 ), what is in accordance with the adopted qualitative scale and it means a high degree of care for providing recipients with functional and safe products and for ensuring adequate working conditions for workers. Hence, great care for products' quality in the examined company was simultaneously an evidence of social responsibility towards other human being in terms of care for his/her needs and expectations. The most counting indicators of quality are high quality of raw materials and professional competences of the employed. The crucial prosocial aspect in this area was raising awareness of the workers about the connection between qualitative requirements in force in the company and equally high expectations of customers.

- In the area of improvement of activity through elimination of losses an average degree of intensification of this type of actions was shown (index 0,51, the standard deviation 0,19). These actions in the examined company consisted in either direct improvement of activities and processes at work or in elimination of waste of materials and raw materials. This second type of actions is appreciated only in the second place. 
The variation of forms of elimination of losses is quite big but they all lead to particular savings. An important element of shaping prosocial working conditions in this area is creating situations, in which workers canformulate their own ideas of corrections and innovations. It releases a sense of co-responsibility for the organisation's resources and their own contribution to increasing rationality of their management and creating values for the stakeholders.

- In the area of axiological orientation of managers' attitudes - an average degree of intensification of the managers' attitudes with social values and ethical standards (index 0,44, the standard deviation 0,14 ). The highest rank is given to values such as: responsibility and reliability. The other values i.e. honesty and justice were less indicated in the responders' responses. Prosocial attitudes of the managers of the examined company require further shaping, however the conducted research undoubtedly pointed out that in situations of experiencing by stakeholders (internal stakeholders and external stakeholders) positive interactions, respecting their needs and expectations and social consequences of economic actions a considerable growth of effects of co-operation with them takes place.

- In the area of subjective treatment of workers it was revealed that in the examined company the workers are treated subjectively at a high degree (index 0,72 ; the standard deviation 0,16 ). The majority of responders feel that they are treated well, appreciated and do not experience behaviours posing crucial threat to their self-esteem. The level of experiencing of subjectivity grows as a result ofhaving particular autonomy on the working position and feeling authorship and importance of one's own actions. The workers of the examined company are aware of the conditions necessary for acquiring independence with different ranges of responsibility. Despite clear manifestations of respecting the subjectivity of the employed, some range of expectations in this respect can still be observed. Nevertheless, the confirmed manifestations show that experiencing fully personal participation in professional situations, a sense of authorship and importance of actions isan extremely essential element of prosocial working environment.

- The general indicator of prosocial involvement in the examined organisation obtained on the basis of partial aggregate indicators situated itself incut-off point starting at high level and it amounted to 0,6 (the standard deviation 0,10). On this basis, one can conclude that in the examined companysocial values express themselves in a practical linking of strategical tasks with satisfying needs of the stakeholders. However, further and systematical actions facilitating respecting of social values in the economic activity are desired for maintaining and the growth of the achieved degree of "prosociality".

The relationship between presented types of actions and general state of prosocial involvementwas statistically confirmed. At relevance level amounting to $\alpha=0,05$ statistically relevant correlations of actions taken in every examined areas and a general state of social involvement in an analysed organisation were stated.

Table 1. A Matrix of Correlations between Social Involvement Indicators in the Selected Areas (correlation coefficients statistically relevant at the level $\alpha=0,05$ are marked with an asterisk)

\begin{tabular}{|c|c|c|c|c|c|}
\hline $\begin{array}{c}\text { CORRELATIONS BETWEEN } \\
\text { INDICATORS }\end{array}$ & $\begin{array}{l}\text { Reliable } \\
\text { implementation } \\
\text { of qualitative } \\
\text { requirements }\end{array}$ & $\begin{array}{l}\text { Improvement } \\
\text { of an activity } \\
\text { through } \\
\text { elimination of } \\
\text { losses }\end{array}$ & $\begin{array}{l}\text { Axiological } \\
\text { attitudes of } \\
\text { managers }\end{array}$ & $\begin{array}{l}\text { Subjective } \\
\text { treatment of } \\
\text { workers }\end{array}$ & $\begin{array}{l}\text { General degree } \\
\text { of prosocial } \\
\text { involvement }\end{array}$ \\
\hline $\begin{array}{l}\text { Reliable implementation of qualitative } \\
\text { requirements }\end{array}$ & 1,000 & 0,130 & $-0,035$ & $0,342 *$ & $0,627 *$ \\
\hline $\begin{array}{l}\text { Improvement of an activity through } \\
\text { elimination of losses }\end{array}$ & 0,130 & 1,000 & 0,012 & $0,205^{*}$ & $0,604 *$ \\
\hline Axiological attitudes of managers & $-0,035$ & 0,012 & 1,000 & $0,206^{*}$ & $0,432 *$ \\
\hline Subjective treatment of workers & $0,342 *$ & $0,205^{*}$ & $0,206^{*}$ & 1,000 & $0,721^{*}$ \\
\hline $\begin{array}{l}\text { General degree of prosocial } \\
\text { involvement }\end{array}$ & $0,627 *$ & $0,604 *$ & $0,432 *$ & $0,721^{*}$ & 1,000 \\
\hline
\end{tabular}

Source: own calculations 
On the basis of the data presented in the Table 1, one can state that cumulating of prosocial actions in specific areas is expressed in the overall growth of prosocial involvement. Particularly, they show that:

- intensification of actions connected with care for high quality of products is accompanied with the growth of general degree of prosocial involvement of the organisation,

-improving of rationality of the enterprise's resource management is accompanied with the growth of general degree of prosocial involvement of the organisation,

-strenghtening of force of axiological attitudes of the managers is accompanied with the growth of the general degree of the organisation's prosocial involvement,

-intensification of manifestations of subjective treatment of the workers is accompanied with the growth of the general degree of the organisation's social involvement.

The indicated correlations simultaneously confirm "participation" of the areas selected for examination as actually examining prosocial orientation of the enterprise. Thus, a justification for formulating an overall evaluation of prosocial involvement on their basis was obtained. The presented results encourage one to consider whether the examined and analysed manifestations of prosocial involvement can constitute criteria allowing to determine and evaluate prosocial conditions of effective functioning the organisation? The exemplary character of the research focused on the one organisation suggests caution in generalisation of the presented results. Although making a decision requires broader research in this respect, yet one should observe essential guidelines for practical introduction of social values into economic activityin the proposal of this criteria.

The obtained results (Table 1) also confirmed the dominant role of subjective treatment of the employees in shaping the analysed phenomenon and taking any socially responsible actions. The statistically relevant correlation between subjective treatment of employees and actions taken in the remaining examined areas was stated. It means that with intensification of the manifestations of subjective treatment of employeesthe growth of care for quality of products, greater diligence in managment (elimination of losses) of the enterprise's resources, and also strengthening of the axiological profile of the managers' attitudes is noticed. The remaining co-correlations between analysed areas of prosocial actions were not statistically confirmed. In the light of foregoing and the results of the qualitative analysis relating to the area of subjective treatment of employees, a conclusion can be proposed that the aspect of subjective treatment of employees constitutes a criterion of key importance, determining success of prosocial actions in other areas of the organisation's functioning. It should be added that "the professional" manifestations of reckoning with the other human being that is careful observance of labour rights or the justified range of autonomy at workplace are the expression of the overall attitude of humane treatment of every employed person.

\section{Conclusions}

Recognition of a degree of prosocial involvement of the examined organisation required obtaining knowledge on the role of social behaviours in achieving assumed strategic objectives and determining to what extent social values and axiological reflection are incorporated in functioning of this organisation. In conducted research this task was carried out in relation to four, presented earlier, areas of the organisation's functioning. The evaluation of prosocial involvement was based on the results of quantitive and qualitive analysis of manifestations of prosocial actions taken in the analysed areas.

The indicated, high degree of prosocial involvement in the examined organisation and qualitative results of the analysis of its manifestations warrant the conclusion that the social dimension of taken economic actions in the company expresses itself, according to the type of examined areas, in four forms:

- in dependence of economic effectiveness on social responsibility towards customers, for quality of products and towards workers for adequate working conditions. Prosocial involvement of the organisation is shaped in this respect by a special care for another human being: the recipient and products manufacturer and responsibility towards him/her.

-in perfection of the economic activity through improving of rationality of resource management of the organisation. Prosocial involvement of the organisation shapes in this respect co-responsibility of all employed for resources and interests of the organisation and respect and recognition for the employee as a particular source of cognitive and creative possibilities.

- in connecting of effectivity of the organisation's management with axiologically oriented attitudes of the managers. Prosocial involvement of the organisation shapes in this respect social valuation and evaluation by 
the managers of economic actions, their course and results.

- in dependence of the growth of economic effectiveness on subjective treatment among the members of the organisation. Prosocial involvement of the organisation shapes in this respect sensitivity and respect towards dignity of the worker and personal determinants of efficient professional action.

The obtained results initially confirmed that the analyzed areas of signs of prosocial involvement can constitute criteria allowing to determine and evaluate prosocial orientation of an organisation with the particular emphasis of the role of subjective treatment of its members.

The quoted conclusions, due to low representativeness of the sampling (they concern one organisation) and the lack of clear causality solutions included in correlation method, do not give right for further generalisation. There were attempts to reduce the limitations of the research by complementing the reasoning with in-depth qualitative analyses. The suggestion for further carrying out of research including a larger group of responders seems to be essential. However, it is worth noticing that the presented conclusions show crucial, and in relation to the issues of workers' subjectivity - even fundamental aspects of shaping of prosocial conditions of the effective economic activity.

\section{Announcement}

The publication was funded from the appropriations of the Faculty of Economics and International Relations of the Cracow University of Economics, within grants for maintaining the research potential.

\section{References}

Adamska-Chudzińska, M. (2012a). Psychosocial Value of Porfessional Work in The Context of Effectiveness of An Employee. In P. Lula, B.Mikuła \& A.Jaki (Eds.), Knowledge - Economy - Society. Transfer of Knowledge in the Contemporary Economy, IV/27 (pp. 359-371). Cracow: Foundation of the Cracow University of Economics.

Adamska-Chudzińska, M. (2012b). Uwarunkowania sprawności zawodowej czlowieka $w$ organizacji. Aspekt prospoleczny. Kraków: Wydawnictwo Uniwersytetu Ekonomicznego w Krakowie.

Adamus-Matuszyńska, A. (2013). Wpływ społecznej odpowiedzialności biznesu na konkurencyjność przedsiębiorstwa. Zeszyty Naukowe Uniwersytetu Przyrodniczo-Humanistycznego. Seria: Administracja $i$ Zarzqdzanie, 25(98), 191-201.

Bartkowiak, G. (2006). Practical Aspects of Social Responsibility in Business. Dialogue and Universalism.Metaphilosophy as Wisdom of Science, Art and Life, 5(6), 134-142.

Bąk, M., Bednarz, P., Kulawczuk, P., Rataj, R., Szcześniak, A., \& Zając, P. (2007). Analiza korzyści ekonomicznych ze stosowania zasad społecznej odpowiedzialności biznesu (CSR) w polskich przedsiębiorstwach. Streszczenie i wnioski. In P. Kulawczuk, \& A. Poszewiecki (Eds.), Wplyw Społecznej Odpowiedzialności Biznesu i Etyki Biznesu na Zarzq̨dzanie Przedsiębiorstwami (pp. 55-112). Warszawa:Instytut Badań nad Demokracją i Przedsiębiorstwem Prywatnym, EQUAL.

Beltratti, A. (2005). The complementarity between corporate governance and corporate social responsibility. The Geneva Paper on Risk and Insurance: Issues and Practice, 30(3), 373-386. http://dx.doi.org/10.1057/palgrave.gpp.2510035

Benz, K. (2010). Corporate Social Responsibility: is it rewarded by the corporate bond market? A critical note. Journal of Business Ethics, 96, 117-134.

Beurden, P., \& Gössling, T. (2008). The Worth of Values - A Literature Review on the Relation Between Corporate Social and Financial Performance. Journal of Business Ethics, 82(2), 407-424. http://dx.doi.org/10.1007/s10551-008-9894-x

Borkowska, S. (2005). CSR-wyzwaniem dla zarządzających zasobami ludzkimi: podejście unijne. Zarzqdzanie Zasobami Ludzkimi, 6, 9-29.

Brik, A., Rettab, B., \& Mellahi, K. (2011). Market orientation, corporate social responsibility and business performance. Journal of Business Ethics, 99(3), 307-324. http://dx.doi.org/10.1007/s10551-010-0658-z

Cetindamar, D., \& Husay, K. (2007). Corporate social responsibility practices and environmentally responsible behaviour: The case of the United Nations Global Compact. Journal of Business Ethics, 76(2), 163-176. 
http://dx.doi.org/10.1007/s10551-006-9265-4

Chi-Shiun, L., Chih-Jen Ch., Chin-Fang Y., \& Da-Chang P. (2010). The effect of corporate social responsibility on brand performance: The mediating effect of industrial brand equity and corporate reputation. Journal of Business Ethics, 95(3), 457-469. http://dx.doi.org/10.1007/s10551-010-0433-1

Chmielecka, E. (2004). Informacja, wiedza, mądrość - co społeczeństwo wiedzy cenić powinno? In K. Kloc \& E. Cmielecka (Eds.), Dobre obyczaje w kształceniu akademickim(pp. 55-64). Warszawa: Fundacja Promocji i Akredytacji Kierunków Ekonomicznych.

Clark, G. L., \& Viehs, M. (2014). The Implications of Corporate Social Responsibility for Investors: An Overview and Evaluation of the Existing CSR Literature. Retrieved August 17 from: http://ssrn.com/abstract=2481877

Doktór, K. (2005). Dylematy społecznej odpowiedzialności organizacji gospodarczych. Zarzadzanie Zasobami Ludzkimi, 6, 36-41.

Filek, J. (2010). The implementation of CSR as a New Social Contract in Poland. In B. Fryzel \& P. H. Dembinski (Eds.), The Role of Large Enterprise in Democracy and Society (pp. 138-159). Houndmills, Basingstoke, Hampshire, New York: Palgrave Macmillian. http://dx.doi.org/10.1057/9780230283138

Frankfort-Nachmias, Ch., \& Nachmias D. (2001). Metody badawcze w naukach społecznych. Poznań: Zysk i S-ka.

Garriga, E., \& Mele D. (2004). Corporate Social Responsibility Theories: Mapping the Territory. Journal of Business Ethics, 53, 51-71.

Gasparski, W. (2007). Wykłady z etyki biznesu. Warszawa: Wyższa Szkoła Przedsiębiorczości iZarządzania.

Godfrey, P., \& Merrill, C. B. (2009). The relationship between corporate social responsibility and shareholder value: an empirical test of the risk management hypothesis. Strategic Management Journal, 30, 425-445.

Hamrol, A. (2013). Zarzadzanie jakościq z przykładami. Warszawa: PWN.

Hediger, W. (2010). Welfare and capital-theoretic foundations of corporate social responsibility and corporate sustainability. The Journal of Socio--Economics, 39(4), 518-526. http://dx.doi.org/10.1016/j.socec.2010.02.001

Jackson, G., \& Apostolakou, A. (2010). Corporate Social Responsibility in Western Europe: An Institutional Mirror or Substitute? Journal of Business Ethics, 94(3), 371-394. http://dx.doi.org/10.2307/40784700

Kamiński, T., \& PomykałoW. (Eds.). (2004). Społeczna rola wspótczesnego marketingu, Materiały konferencyjne. Warszawa:Wyższa Szkoła Ekonomiczno-Informatyczna.

Kang, Y. Ch., \& Wood, D.J. (1995). Before Profit Social Responsibility Turning the Economic Paradigm Upside Down. In D. Nighand \& D. Collins (Eds.), Proceedings of the Sixth Annual Meeting of the International Association of Business and Society (pp. 408-418). Vienna.

Kot, S. M ., Jakubowski, J., \& Sokołowski, A. (2010). Statystyka. Warszawa: Difin.

Lewicka-Strzałecka, A. (2006). Odpowiedzialność moralna w życiu gospodarczym. Warszawa: Instytut Filozofii i Socjologii PAN.

Logman, D. (2002). A Global Force of Goods. London: Corporate Citizenship Company.

Lopez, M., Garcia, A., \& Rodriguez, L. (2007). Sustainable Development and Corporate Performance: a study based on Dow Jones Sustainability Index. Journal of Business Ethics, 75(3), 285-300. $\mathrm{http}: / / \mathrm{dx}$. doi.org/10.1007?s10555-006-9253-8

Low, J., \& Kalafut, P. (2004). Niematerialna wartość firmy. Warszawa: Oficyna Wydawnicza.

Lulewicz-Sas, A. (2013). Wpływ podejmowanych przez przedsiębiorstwa inicjatyw społecznie odpowiedzialnych na wartość organizacji. Economics and Management, 2, 242-254. http://dx.doi.org/10.12846/j.em.2013.02.15

Maignan, I., \& Ferrell, O. (2004). Corporate Social Responsibility and Marketing: An Integrative Framewor. Academy of Marketing Science, 32(1), 3-19. http://dx.doi.org/10.1177/0092070303258971

Maksimainen, J., Saariluoma, P., \& JakivuoriP. (2012). Corporate Social Responsibility and Values in Innovation Management. International Journal of Social Sciences, 5(2), 97-101.

Marcinkowska, M. (2010). Społeczna odpowiedzialność przedsiębiorstw a ich wyniki ekonomiczne-aspekty teoretyczne. Przeglad Organizacji, 10, 7-10.

Morsing, M. (2009). Koncepcja społecznej odpowiedzialności biznesu w nauce o zachowaniach w organizacji. In 
N.C. Smith \& G. Lenssen (Eds.), Odpowiedzialność biznesu. Teoria i praktyka (pp. 466-474). Warszawa: Studio Emka.

Penc, J. (2007). Nowoczesne kierowanie ludźmi. Wywieranie wpływu i współdziałanie w organizacji. Warszawa: Difin.

Pociecha, J., Podolec, B., Sokołowski, A., \& Zając, K. (1988). Metody taksonomiczne w badaniach spoteczno-ekonomicznych. Warszawa: Wydawnictwo Naukowe PWN.

Pratley, P. (1995). The Essence of Business Ethics. New Jersey: Prentice Hall.

Rok, B. (2004). Odpowiedzialny biznes w nieodpowiedzialnym świecie. Warszawa: Akademia Rozwoju Filantropii w Polsce, Forum Odpowiedzialnego Biznesu.

Roszkowska, P. (2011). Rewolucja w raportowaniu biznesowym. Interesariusze, konkurencyjność, społeczna odpowiedzialność. Warszawa: Difin.

Rybak, M. (2012). Etyka menedżera-spoleczna odpowiedzialność przedsiębiorstwa. Warszawa: Wydawnictwo Naukowe PWN.

Silverman, D. (2013). Doing Qualitative Research. (4 ${ }^{\text {th }}$ ed.). Los Angeless, London, New Delhi, Singapore, Washington, DC: Sage.

Silverman, D. (2014). InterpretingQualitative Data (5 ${ }^{\text {th }}$ ed.).. Los Angeless, London, New Delhi, Singapore, Washington, DC: Sage.

Sokołowski, A. (2010). Dlaczego warto znać metody statystyczne i data mining? Statistica w badaniach naukowych $i$ nauczaniu Statystyki (pp. 103-126). Kraków: StatSoft Polska.

Surroca, J., Tribo, J., \& Waddock, S. (2010). Corporate responsibility and financial performance: the role of intangible assets. Strategic Management Journal, 31(5), 463-490. http://dx.doi.org/10.1002/smj.820

Sztumski, J. (1984). Wstęp do metod i technik badań spolecznych. Warszawa: Wydawnictwo Naukowe PWN.

Wach. K. (2015). Impact of Cultural and Social Norms on Entrepreneurship in the EU: Cross-Country Evidence based on GEM Survey Results. Zarzadzanie $w$ Kulturze, 16(1), 15-29. http://dx.doi.org/10.4467/20843976ZK.15.002.3037

Wagner, M. (2009). Innovation and competitive advantages from the integration of strategic aspects with social and environmental management in European firm. Business Strategy and the Environment, 18(5), 291-306. http://dx.doi.org/10.1002/bse.585

Wojtczuk-Turek, A. (2008). Zaangażowanie jako istotny wymiar postawy pracownika wobec pracy. Edukacja Ekonomistów I Menedżerów, 3(10), 25-45.

Wood, D. J. (2010). Measuring Corporate Social Performance: A Review. International Journal of Management Reviews, 12(1), 50-84. http://dx.doi.org/10.1111/j.1468-2370.2009.00274.x

Xuereb, N. (2009). The Maltese Foudation: A Vehcle for Corporate Social Resposibility. Mondaq Business Briefing, October 5.

\section{Note}

Note 1. One can read the comprehensive presentation of detailed data with graphic illustrations in the earlier work of the author (Adamska-Chudzińska, 2012b, pp. 150-198). 